\title{
Microbiome and morbid obesity increase pathogenic stimulus diversity
}

\author{
Björn L.D.M. Brücher ${ }^{1,2,3,}{ }^{*}$, Ijaz S. Jamall ${ }^{1,2,4}$ \\ ${ }^{1}$ Theodor-Billroth-Academy ${ }^{\circledR}$, Germany, USA \\ ${ }^{2}$ INCORE, International Consortium of Research Excellence of the Theodor-Billroth-Academy ${ }^{\circledR}$, Germany, USA \\ 3 Department of Surgery, Carl-Thiem-Klinikum, Cottbus, Germany \\ ${ }^{4}$ Risk-Based Decisions Inc., Sacramento, CA, USA
}

Received 22 March 2018, Accepted 21 November 2018

\begin{abstract}
The microbiome, the relationship between environmental factors, a high-fat diet, morbid obesity, and host response have been associated with cancer, only a small fraction of which $(<10 \%)$ are genetically triggered. This nongenetic association is underpinned by a worldwide increase in morbid obesity, which is associated with both insulin resistance and chronic inflammation. The connection of the microbiome and morbid obesity is reinforced by an approximate shift of about $47 \%$ in the estimated total number of bacteria and an increase from $38,000,000,000,000$ in a reference man to $56,000,000,000,000$ in morbid obesity leading to a disruption of the microbial ecology within the gut. Humans contain 6,000,000,000 microbes and more than $90 \%$ of the cells of the human body are microorganisms. Changes in the microflora of the gut are associated with the polarization of ion channels by butyrate, thereby influencing cell growth. The decrease in the relative proportion of Bacteroidetes together with a change in the fermentation of carbohydrates by bacteria is observed in morbid obesity. The disruption of homeostasis of the microflora in the obese changes signaling and crosstalk of several pathways, resulting in inflammation while suppressing apoptosis. The interactions between the microbiome and morbid obesity are important to understand signaling and crosstalk in the context of the progression of the six-step sequence of carcinogenesis. This disruption of homeostasis increases remodeling of the extracellular matrix and fibrosis followed by the none-resolvable precancerous niche as the internal pathogenic stimuli continue. The chronic stress explains why under such circumstances there is a greater proclivity for normal cells to undergo the transition to cancer cells.
\end{abstract}

Keywords: Cancer, Carcinogenesis, Signaling, Chronic inflammation, Fibrosis, Precancerous niche, Somatic mutation theory, Cell transition, Microbiology, Microbiome, Microflora, Virology, Viriome

\section{Introduction}

Microbiology research is changing rapidly, as stated by the American Society of Microbiology (ASM) based on new technologies, globally relevant infectious diseases, and increased resistance to antibiotics [1,2]. Understanding the impact of microbiology on evolution and environment is significant and cultures of microbes may be transformed to the virtual microbial cell and we still do not know how artificial intelligence may impact our future understanding of microbiology- and metabolic-driven pathways or their global linkages. Despite the numbers of microbes-driven impact on our understanding of various diseases [3-5], it might not be an understatement that microbiology has driven and still influences life and health $[6,7]$.

\footnotetext{
*Corresponding author: b-bruecher@gmx.de
}

Changes in the microflora of the gut are associated with the polarization of ion channels by butyrate, thereby influencing cell growth. The microbiome, the relationship between environmental factors, a high-fat diet, morbid obesity, and host response have been associated with cancer, only a small fraction of which $(<10 \%)$ are genetically triggered. This nongenetic association is supported by a worldwide increase in morbid obesity, which is associated with both insulin resistance and chronic inflammation. The disruption of homeostasis [8] of the microflora in morbid obesity changes signaling and crosstalk of several pathways, which results in inflammation while suppressing apoptosis.

The interactions between the microbiome and morbid obesity are important to understand signaling and crosstalk in the context of carcinogenesis. This disruption of homeostasis increases remodeling of the extracellular matrix and fibrosis followed by the none-resolvable 
Table 1. Microbes in humans and on earth in accordance to references $[1,2]$.

\begin{tabular}{llll}
\hline & Microbes & Humans & Factor \\
\hline On Earth & $5 \times 10^{31}$ & $6 \times 10^{9}$ & $\sim 10^{22}$ \\
Mass (metric tons) & $5 \times 10^{16}$ & $3 \times 10^{8}$ & $\sim 10^{8}$ \\
Generation time & 30 min & 30 years & $\sim 5 \times 10^{5}$ \\
Time on Earth/years & $3.5 \times 10^{9}$ & $4 \times 10^{5}$ & $\sim 10^{4}$ \\
\hline
\end{tabular}

precancerous niche $(\mathrm{PCN})$ as the internal pathogenic stimuli with pro-inflammatory mediators ensues [9]. The chronic stress response by the body explains why there is a greater proclivity for normal cells to undergo the transition to cancer cells.

\section{Microbiome (Tab. 1)}

The reality in terms of the numbers of microbes on earth with its mass generation time and time on Earth had been provided recently by the American Society of Microbiology (ASM) [1]. Humans did not exist while microbes collective experience creating and defeating antibiotics for 20 million times longer than Homo sapiens have known that antibiotics existed [2]. Resistance against antibiotics will occur and any attempt to enhance the immune system will be limited in utility - just a complementary approach as pointed out by Spellberg et al. The numbers provided are amazing as more than 50 quadrillion metric tons microbial cells, $5 \times 10^{31}$ $(50,000,000,000,000,000,000,000,000,000,000)$ on earth with much shorter generation times compared to humans (factor $\sim 5 \times 10^{15}$ ) increase the diversity of life.

Mammalian intestines contain an estimated $10^{10}$ to $10^{14}$ microbial cells, which is about 10 -fold greater than the number of host cells [3]. The colon has about $10^{14}$ bacteria [4]. The estimate of the total number of bacteria for a $70 \mathrm{~kg}$ individual is about $3.8 \times 10^{13}$, which shows that the number of bacteria in the body is on the same order as the number of human cells though the bacterial total mass is estimated to be only about $0.2 \mathrm{~kg}$ [5]. This number is approximately equal to the estimated $10^{13}$ eukaryotic animal cells in an adult human [6].

From the ileum to the cecum there is a bacterial gradient ranging from approximately $10^{8}$ bacteria/g to about $10^{11}$ bacteria/g as measured in feces [5]. By assuming that red blood cells account for $84 \%$ of the total host cells for the reference man, an increase in total bacterial gradient was estimated to occur from an infant of 4 weeks $\left(4.4 \times 10^{12}\right)$, a toddler of $1 \mathrm{y}$ of age $\left(7 \times 10^{12}\right)$, to a $20-30$ year reference man of $70 \mathrm{~kg}\left(38 \times 10^{12}\right)$, a reference woman of $63 \mathrm{~kg}\left(44 \times 10^{12}\right)$, and an older person of 66 years $\left(38 \times 10^{12}\right)$ compared to an obese person of $140 \mathrm{~kg}$ with $56 \times 10^{12}[5]$. This means an increase of about $47 \%$ from $38 \times 10^{12}$ in a reference man to $56 \times 10^{12}$ in the morbidly obese. Therefore, it comes as no accident that there is not just a shift of total numbers of microorganisms but also a disruption of the microbial homeostasis within the gut in morbid obesity associated with a decrease in the relative proportion of Bacteroidetes [7].

The numbers provided reveals that de-emphasizing the focus on the host (human body) to a genetic reservoir is not enough. The microbiome with its diversity influences our life and often serves as pathogenic stimuli initiating chronic inflammation [8]. The diversity of the microbiome can result in a dysbiosis triggering a disruption of homeostasis of pro- and anti-inflammatory mediators [9]. Of course, the importance of oral hygiene is well known to be associated with periodontitis, oral plaques, etc. However, affecting the host should not be seen within a localized context as chronic inflammation has much wider effects.

The gram-negative anaerobic Tannerella forsythia induces activation of inflammatory cells with increase of interleukin 6 (IL-6), and its bacterial entry is dependent on phosphatidylinositol 3-kinase (PI3K), protein kinase B (Akt, PKB), and host Ras-related C3 botulinum toxin substrate 1 (Rac1) guanosine-5'-triphosphate (GTP)ase, and its endocytosis, which needs lipid microdomains and clathrin [10].

T. forsythia expresses two sialidases, SiaHI and NanH, which are important in bacterial colonization [11]. Oral microbiome composition alters fatty acid metabolism [12] and are not just associated with oral cancer development [13] but also are suspected of promoting esophageal $[14,15]$, pancreatic cancer [16,17], or liver cancer [18]. $T$. forsythia "contributes to the growth of a partner species, Fusobacterium nucleatum, in co-biofilms" [19]. $F$. nucleatum is associated with the precancerous serrated adenoma of the proximal colon [20] and various cancers $[21,22]$.

We assert that the renaissance in microbiology for cancer research has commenced and that it needs an increased effort with close interdisciplinary impact and collaboration between various disciplines.

The Human Microbiome Project (HMP) showed that there is no single healthy microbiome [23] and that there might also be no unhealthy microbiome. The gut microbiome is associated with metabolic signaling pathways such as tumor necrosis factor alpha $(\mathrm{TNF} \alpha)$ and interferon gamma (IFN $\gamma$ ) through palmitoleic acid and tryptophan metabolism [24]. The palmitoleic acid metabolism was associated with cancer as "...significantly lower content of palmitoleic acid compared to their counterpart non-stem cancer cells" were shown [25].

An explanation was suggested by the demonstration that distant bioelectric signaling suppressed cancer growth by misexpression of hyperpolarizing ion channels and that this effect was mediated by the short-chain fatty acid, butyrate, which is usually produced in the colonic mucosa through bacterial fermentation of carbohydrates [26]. If these findings are reproducible, one plausible way to prevent cancer might be to re-program gut microorganisms to produce butyrate. However, there is evidence that different single components of the microbiome may trigger carcinogenesis through the recently proposed six-step sequence which includes pathogenic biological 
stimuli that provoke subclinical chronic inflammation leading to fibrosis with remodeling of the extracellular matrix (ECM) resulting into a precancerous niche (PCN) [27].

Proteomic analysis can help to identify biological processes that could be of importance in carcinogenesis [28]. Schistosoma haematobium was associated with bladder cancer using proteomic profiling [29]. Products of the nematode, Anisakis pegreffi, were shown to upregulate heat shock protein 70 (Hsp70) with a corresponding decrease in apoptosis [30].

There is also an attempt to use RNA profiling data using differential expression to assess if these data "are sufficient to make the normal and redirected gene expression states indistinguishable from each other but radically different from the tumor state" [31].

It has been proposed that multitargeted cancer therapy against multiple markers could be of future benefit [32]. However, such an approach using RNA would need to differentiate between the different types of RNA. For example, transfer RNAs (tRNAs; synonym: soluble RNA, sRNA) help decode messenger RNA (mRNA) to form a protein and each codon represents a particular amino acid that is recognized by a specific tRNA. tRNA carries an amino acid to the ribosome (directed by a threenucleotide-sequence in a mRNA) and one tRNA end matches the genetic code (called an anticodon). The involvement of tRNA pathways in cell proliferation and tumorigenesis was recently shown by analyzing breast and prostate cancer cell lines [33]. Furthermore, some $80 \%$ of RNAs are short-lived and exist for less than 2 min [34]. This is relevant as protocols used to investigate RNA would have to stipulate the stability of the RNA used, and if stored or frozen, RNA pellets were reconstituted after fluids and/or tissue samples were collected and thus provide information about the quality of material used.

Western diets (typically high in animal protein, sugar, starch, fat, and low in fiber) can trigger chronic systemic inflammation [35] and influence the composition of the intestinal microbiota [36]. The composition of the microbiome in humans is associated with cancer. A greater gut bacterial diversity was tied to slower metastatic melanoma progression, while the patient group with higher bacterial diversity had not reached the median progression free survival (PFS) (more than half had not even progressed), whereas those with intermediate and low bacterial diversity had median PFS of 232 and 188 days, respectively [37]. Patients responding to immunotherapy showed increased levels of Ruminococcaceae, while nonresponding patients showed enriched Bacteroidales. This was interpreted as relevant since patients who had a high abundance of the genus Faecalibacterium (of the Ruminococcaceae family and Clostridiales order) in their gut exhibited significantly prolonged PFS (median not reached) as compared to patients who had a low abundance (median PFS of 242 days). Moreover, the greater abundance of Bacteroidales was associated with more rapid disease progression in melanoma, with high abundance within the gut microbiome associated with significantly reduced PFS (median 188 days) compared to low abundance (median PFS of 393 days). Additionally, immunotherapy responders showed high levels of the beneficial Clostridiales/Ruminococcaceae, including greater $\mathrm{T}$ cell penetration into tumors and higher levels of circulating $\mathrm{T}$ cells that kill abnormal cells. Those with abundant Bacteriodales had higher levels of circulating regulatory $\mathrm{T}$ cells, myeloid-derived suppressor cells, and a blunted cytokine response resulting in a dampening of antitumor immunity.

Pattern recognition receptors (PRRs) include the membrane-bound Toll-like receptors (TLRs) and C-type lectins (CTLs) and are expressed in macrophages, monocytes, neutrophils, epithelial cells and cells of the innate immune system that stimulate inflammation [38]. Receptors recognizing pathogens contain NOD-like receptors (NLRs) and were reported as a novel class of PRRs. NLRs are sensors of pathogen-associated molecular patterns (PAMPs) and host-derived danger signals; danger-associated molecular patterns (DAMPs) lead to an inflammatory response (reviewed in [39-41]). NLRs contain a NOD-, leucine-rich repeat (LRR) NLR and pyrin domain-containing 1 and include NACHT, LRR and PYD domain-containing protein 3 (NLRP3, NALP3), NLR family CARD domain-containing protein 4 (NLRC4), NACHT, LRR, and PYD domain-containing protein 6 (NLRP6), NACHT, LRR and PYD domain-containing protein 7 (NLRP7), NACHT, LRR and PYD domaincontaining protein 12 (NLRP12) or NLRC4 [42].

In encephalomyelitis NLRP12 negatively regulates the nuclear factor-kappa B (NF-kB) pathway suppressing inflammation [43].

In NLRP12-deficient mice, NF-кB activation is increased in association with colitis-associated colon cancer [44], which is in accordance with low-expressed NLRP12 in precancerous ulcerative colitis [45]. Human adipose tissues of obese patients have decreased NLRP12 levels and knockout results in weight gain and chronic inflammation [46]. NLRP12 maintained colon microbiome diversity, attenuated colon inflammation, and promoted specific microbes that reversed gut inflammation [45]. Thus, NLRP obesity protection is dependent on the microbiome [46]. NLRP12 was reported as a regulator of homeostasis for inflammation and NF-кB signaling pathway and crosstalk [47], but the microbiome data reviewed [45,46] may provide evidence about the important influence of the microbiome with dysbiosis on chronic inflammation, obesity, and the consequent disruption of homeostasis.

Colonic microbiota investigated together with host response genes in fecal and mucosal samples from colorectal cancer (CRC) patients compared to patients with polyps and healthy controls revealed microbiota composition in regard to localization of the primary tumor [48]. The authors stratified the patients in accordance with tissue-associated microbial co-abundance Groups (CAGs). Concerns were raised in terms of microbiota based on cancer site due to the wide variability in the microbiota data [49] and the authors reanalyzed their data in accordance to CAGs and reported that two CAGs at 
surgery were associated with longer survival in CRC together with an association of "pre-surgery faecal microbiota with stability of the microbiota after surgery" [50]. The same group investigated microbiota in oral swabs and compared it to results from colonic mucosae and stool probes in CRC and stated that "high abundance of Lachnospiraceae was negatively associated with the colonisation of colonic tissue with oral-like bacterial networks suggesting a protective role for certain microbiota types against CRC, possibly by conferring colonisation resistance to CRC-associated oral taxa and possibly mediated through habitual diet" [51]. However, investigating microbiota is not enough [52] as dynamic changes need to be considered [53].

However, the approach of the disruption of signaling homeostasis-induced crosstalk in the carcinogenesis paradigm "Epistemology of the origin of cancer" is strongly supported by the evidence provided within the various publications of this Special Issue and in terms of the microbiome as dysbiosis with changes in inflammation together with cancer development along the adenomacarcinoma sequence has been provided [54] without any mutation.

The microbiome is studied in an effort to understand morbid obesity as a metabolic condition beyond just caloric intake [55]. In this context, it has been shown that microbial flora from the cecum of obese mice when introduced into germ-free mice resulted in increased obesity even with lower food consumption while the reverse, introducing bacterial flora from lean mice, resulted in weight loss [56]. Furthermore, it has also been shown that a relationship exists between environmental factors and the host insofar as a high-fat diet appears to promote intestinal cancers leading to the hypothesis that antibiotics might block or otherwise mitigate such cancers. More recently, it was shown that the changes in the composition of the intestinal flora (=dysbiosis) may be causally responsible for this observed increase in intestinal cancer incidence [57]. In all likelihood, chronic inflammation induced by morbid obesity could lead to fibrosis with consequent remodeling of the ECM, which in turn, facilitates the transition of a normal cell to a cancer cell.

\section{Morbid obesity}

Morbid obesity is associated with various diseases which, in turn, are themselves associated with chronic inflammation such as is known for cardiovascular diseases, noninsulin-dependent diabetes mellitus (NIDDM), osteoarthritis, and cancer [55]. Lack of physical activity combined with excessive caloric intake along with other factors such as socioeconomic variables, as well as psychiatric and/or metabolic diseases are some of the explanations given for the rise of morbid obesity [58]. Genetics can explain an estimated $7 \%$ of obesity [59].

The body mass index (BMI) does not allow one to distinguish lean body mass from fat body mass. Patients with coronary artery diseases or heart failure over 65 years of age with moderate obesity $(\mathrm{BMI}=30-35)$ compared to normal weight people $(\mathrm{BMI}=20-25)$ and morbidly obese $(\mathrm{BMI}>35)$ revealed a decrease in mortality [60]. This paradox was published first in 1999 ([61], reviewed in [62]) and has so far not been satisfactorily explained.

Morbid obesity can be viewed as an internal pathogenic stimulus triggering carcinogenesis because of its association with subclinical inflammation in adipose tissue [63-66] even though its precise role is not fully understood. Diagnostic upper gastrointestinal endoscopies in morbidly obese patients revealed that some $80 \%$ exhibit pathologic findings in spite of the fact that most such patients are asymptomatic [67].

Obesity has been strongly associated with precancerous lesions and conditions such as colon adenomas [68-86], monoclonal gammopathy [87-98], chronic pancreatitis [99-102], or inflammatory bowel disease (IBD) [103-106]. Observed risks of cancers associated with obesity include breast [107-111], colorectal [112-115], pancreatic [99-102,116], endometrial [117], prostate [118], renal cell carcinoma [119], and lymphoma or leukemia [87-98,120]. Furthermore, obesity is linked to multiple cancers and a nationwide study in Germany suggested preventive potential in these obesity-associated cancers [121].

The paradox that obesity was also reported with nonsignificant associations of obesity and patient outcomes in lymphoma [122] or with improved survival in lymphoma [123-125] is not well understood. Otherwise, bariatric surgery with induced weight loss resulted in regression of hepatocellular carcinoma (HCC) [126], highlighting the significance of morbid obesity with chronic inflammation in carcinogenesis.

Obesity increases resistance against anti-vascular endothelial growth factor (VEGF) drugs due to the ongoing pro-inflammatory cytokine IL-6 and the profibrotic mediator fibroblast growth factor 2 (FGF-2) which result in decreased sensitivity against anti-VEGF therapy [127]. We contend that the ongoing chronic inflammation continuously promotes the creation of the PCN. Furthermore, it should be noted that metformin inhibited FGF-2 in the experiments (Figs. $7 \mathrm{a}$ and $7 \mathrm{~b}$ of Ref. [127] not shown here). ECM remodeling activated by obesity with its underlying chronic inflammation suggests that obesity or chronic inflammation is not enough as it needs fibrosis, which is subsequently remodeled for aggressive cancer phenotype cells that show enhanced growth and invasiveness [128].

One plausible explanation might be to examine how chronic inflammation induced by morbid obesity explains its association with carcinogenesis as has been previously suggested to examine how nuclear factor kappa-lightchain-enhancer of activated $\mathrm{B}$ cells $(\mathrm{NF}-\mathrm{\kappa} \mathrm{B})$ signaling plays a crucial in carcinogenesis [27], and how inhibition of the pro-inflammatory inhibitor of kappa $\mathrm{B}$ kinase beta $(\operatorname{IKK} \beta) / \mathrm{NF}-\mathrm{\kappa B}$ signaling has been shown to be a central pathway in regard to high-fat diet-induced obesity and glucose intolerance [129]. Exogenous fat-induced insulin resistance develops by endogenous fatty acid synthesis in macrophages through modulation of the plasma membrane and through chronic inflammation [130]. 
Inflammation in adipose tissue (Fig. 1) occurs with early-onset insulin resistance by phosphatidylinositol-4,5bisphosphate 3-kinase catalytic subunit gamma isoform (PI3K $\gamma$ ) activity in leukocytes; PI3K $\gamma$ affects macrophage gene expression by non-cell autonomous mechanisms, e.g., autocrine cytokines [131]. Inflammation in obesity is activated by G-protein coupled receptor family $\mathrm{C}$ group 5 member B (GPRC5B) in adipocytes linking GPRC5B diet-induced obesity to type 2 diabetes (T2D) [132]. Morbid obesity-induced inflammation facilitates cancer progression by neutrophils that are recruited by adipocyte-secreted interleukin beta 1 (IL- $\beta 1$ ) resulting in chronic inflammation, which, if persistent, can result in fibrosis and the development of the PCN [133].

The cytokine chemokine ( $\mathrm{C}-\mathrm{X}-\mathrm{C}$ motif) ligand 1 (CXCL1) (synonyms: melanoma growth-stimulating activity alpha, GRO1, GRO $\alpha$; neutrophil-activating protein 3 (NAP3), fibroblast secretory protein (FSP)), is released by macrophages, neutrophils, and the epithelium. CXCL1 binds neutrophils at sites of inflammation, is activated by RAS [134], and is reported to be a mitogen [135].

T2D is associated with $\beta$ cell stress and chronic inflammation as well as subclinical pancreatitis, which increases CXCL1 and triggers proliferation in the human pancreatic ductal epithelium [136]. Interleukin 17 (IL-17) induces the expression of regenerating islet-derived protein 3-beta (REG3 $\beta$ ), which is a mediator of pancreatitis during acinar-to-ductal metaplasia and in early pancreatic intraepithelial neoplasia (PanIN) lesions. The REG3ß glycoprotein130 (gp130)/Janus kinase 2 (JAK2)/ signal transducers and activators of transcription (STAT3)-dependent pathway decreases sensitivity to cell death, thereby promoting cell growth. The genetic inactivation of REG3 $\beta$ in the context of Kras-driven pancreatic ductal adenocarcinoma (PDAC) resulted in reduced PanIN formation, an effect that could be rescued by the administration of exogenous REG3 $\beta$ [137].

Plasminogen activator inhibitor-1 (PAI1) is produced in the endothelium of blood vessels and in adipocytes and is increased in obesity as well as in cancers. Interestingly, PAI1 promotes fibrosis (Fig. 1) by the pathologic disruption of connective tissue and is increased by Angiotensin II and associated with another chronic disease, atherosclerosis.

ORM1 (synonyms: $\alpha 1$-acid glycoprotein, orosomucoid, $\alpha 1$ Agp, AGP, AAG) is synthesized in hepatocytes as an acute phase protein and stabilized by interaction with the PAI1 inhibitory activity [138]. Thus, morbid obesity is associated with an increase of PAI1 by adipocytes, is an inhibitor of fibrinolysis (Fig. 1), and can promote fibrosis, which is also increased by Angiotensin II. These factors may serve to explain why morbid obesity is associated with fibrosis [139]. Furthermore, adipocytes can affect a continuous increase of PI3K and chronic PI3K as well as transforming growth factor beta 1 (TGF- $\beta 1$ ) and these, in concert, result in Akt-mediated SNAIL-stabilization [140] necessary for generating metalloproteinase 1 (MMP-1) and metalloproteinase 7 (MMP-7). There is also a decrease of the forkhead box protein O3a (FOXO3a) associated with increases of Bcl-2-like protein 11 (Bim) and p53 upregulated modulator of apoptosis (PUMA), inhibiting apoptosis [141]. Consequently, anti-apoptotic proteins such as caspase-8 inhibitor and CASP8 and Fas-associated protein with death domain (FADD)-like apoptosis regulator (FLIP) are upregulated [142], which result in lowered internal protection against oxidative stress.

The gene for leptin was discovered by Friedmann and coworkers in 1994 [143]. Leptin is produced by adipocytes and promotes the synthesis of $\alpha$-melanocyte-stimulating hormone $(\alpha-\mathrm{MSH})$ within the medial hypothalamus resulting in the inhibition of hunger. It further counteracts the hunger promotor, 36-amino acid neuropeptide (neuropeptide Y, NPY), within the lateral hypothalamus [144-146], which is released in the gut and the hypothalamus and $N$-arachidonoylethanolamine (anandamide, AEY) [147] and is synthesized by $N$-arachidonoyl phosphatidylethanolamine (NAPE) through an $\mathrm{N}$-acyltransferase enzyme stimulating satiety [148].

Physiological levels of leptin result in selective suppression of $\mathrm{TNF} \alpha$ in macrophage subpopulations by food withdrawal as a centrally mediated anti-inflammatory effect, which is incompletely understood [149].

Paradoxically, leptin has an anti-hunger effect, yet increased levels are found in morbid obesity compared to normal-weight individuals [150], an observation of leptin resistance akin to insulin resistance seen in diabetics. Leptin is similar to the inflammatory cytokine, Il-6 [151], and has an inflammatory [152] and pro-carcinogenic effect via the Janus kinase/signal transducers and activators of transcription (Jak/STAT3) pathway, PI3K/Akt pathway, through up-regulating cyclin-dependent kinase 2 (cdk2, cell division protein kinase 2 ) and cyclin D1, activating the mitogen-activated protein kinase (MAPK) pathway (through extracellular signalregulated kinase 1 (Erk1) and extracellular signalregulated kinase 2 (Erk2) phosphorylation) and also by stimulating the STAT3 pathway and up-regulation of c-myc (one target gene of STAT3) ([153], reviewed in [154]).

Leptin results in a six-fold reduction of apoptosis, an increase in angiogenesis [155], and increases in cultured cytotrophoblastic cells in a dose-dependent manner with metalloproteinase 2 (MMP-2), and fetal fibronectin $(\mathrm{fFN})$, which itself promotes and elevates metalloproteinase 9 (MMP-9) activity ([156,157], reviewed in [155]).

Apoptosis is reduced through stimulation of NF- $\mathrm{BB}$ signaling ([158], reviewed in [155]). Apoptosis is inhibited by leptin in chondrocytes through upregulation of lysyl oxidase-like 3 (LOXL3) mRNA expression via activation of mammalian target of rapamycin complex 1 (mTORC1) [159] (Fig. 1), while the lysyl oxidase inhibitor, $\beta$-aminopropionitrile (BAPN), reduces leptin's pro-fibrotic effects and ameliorates cardiovascular remodeling in diet-induced obesity in rats [160]. Otherwise, leptin-replacement therapy results in cancerrelated adverse effects [161]. 


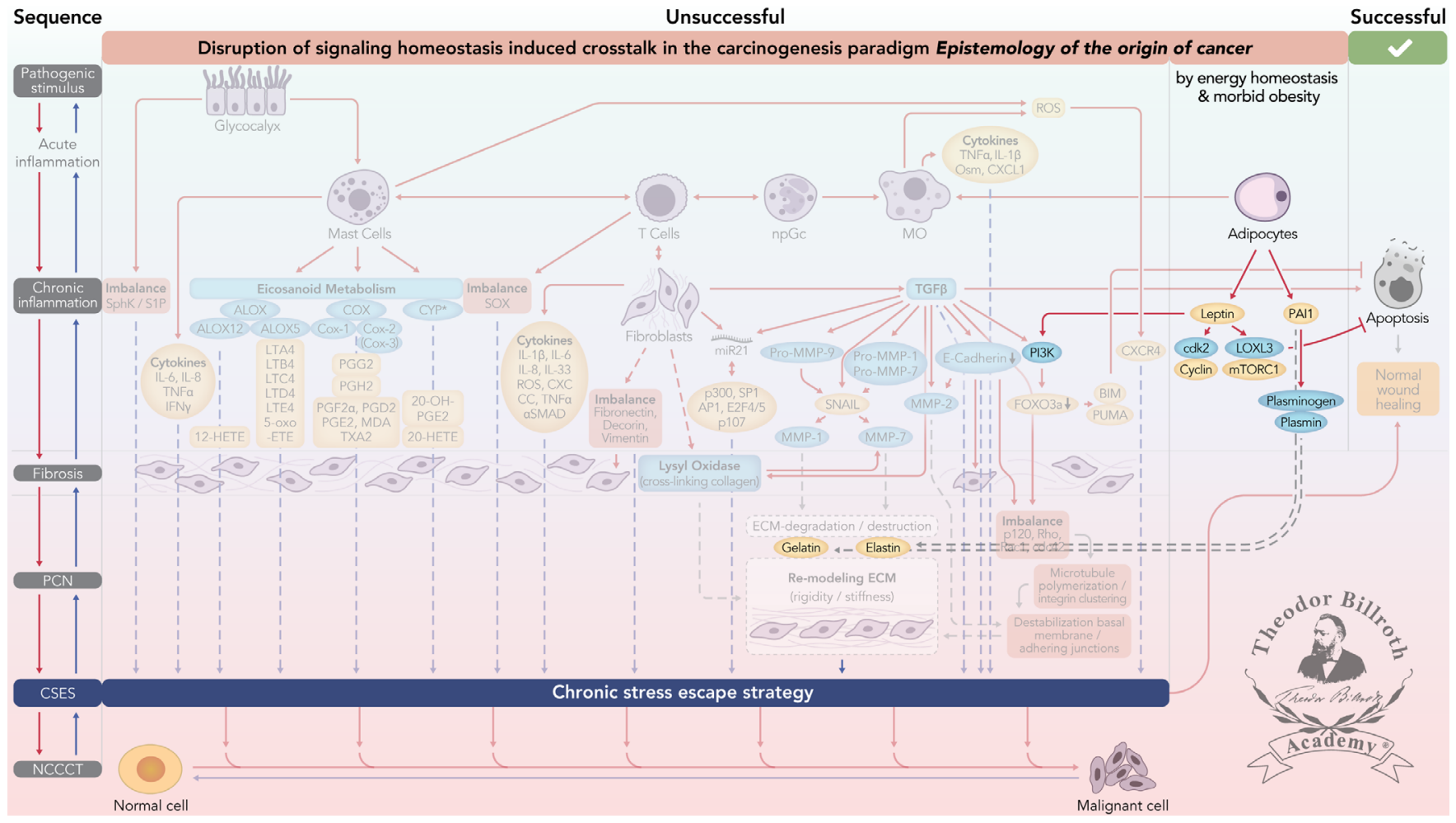

Fig. 1. Simplified scheme of the disruption of signaling homeostasis-induced crosstalk in the carcinogenesis paradigm "Epistemology of the origin of cancer" focusing on energy homeostasis and morbid obesity. The scheme consists of a six-step sequence: (1) a pathogenic stimulus followed by (2) chronic inflammation from which develops (3) fibrosis with associated remodeling of the cellular microenvironment; and from these changes a (4) precancerous niche (PCN), a product of fibrosis, with remodeling by persistent inflammation, develops, which triggers the deployment of (5) a chronic stress escape strategy, and when this fails resolve it by (6) normal cell to cancerous cell transition (NCCCT) by PCN-induced cell matrix stress. This figure was published as original illustration in paper 3 of this Special Issue - Disruption of homeostasis-induced signaling and crosstalk in the carcinogenesis paradigm "Epistemology of the origin of cancer" entitled "Chronic inflammation evoked by pathogenic stimulus during carcinogenesis". We point out, that to the complexity of the content of the Special Issue the original and/or modified version of the original illustration was republished within the following papers of the Special Issue: paper 5 "Microbiome and morbid obesity increase pathogenic stimulus diversity", paper 6 "Precancerous niche (PCN), a product of fibrosis with remodeling by incessant chronic inflammation", paper 7 "Metformin alters signaling homeostasis", paper 8 "Transition from normal to cancerous cell by precancerous niche (PCN) induced chronic cell-matrix stress" and paper 9 "NF-кB signaling and crosstalk during carcinogenesis". Nomenclature: The nomenclature common abbreviations are in bold, followed by the common trivial names (if available) and (if available) by the name in accordance to the International Union of Pure and Applied Chemistry (IUPAC): PCN precancerous niche; CSES chronic stress escape strategy; NCCCT normal cell to cancerous cell transition; SphK sphingosine kinase isoform; S1P sphingosine-1-phosphate; IL-6 interleukin 6; IL-8 interleukin 8; TNF $\boldsymbol{\alpha}$ tumor necrosis factor alpha; IFN $\boldsymbol{\gamma}$ interferon gamma; ALOX lipoxygenase, arachidonate lipoxygenase; ALOX12 12-lipoxygenase, 12-LOX, 12S-LOX, arachidonate 12-lipoxygenase 12S type; ALOX5 5-lipoxygenase, 5-LOX, arachidonate 5-lipoxygenase; 12-HETE 12-hydroxyeicosatetraenoic acid; LTA4 leukotriene A4, 4-[(2S,3S)-3-[(1E,3E,5Z,8Z)tetradeca-1,3,5,8-tetraenyl]oxiran-2-yl]butanoic acid; LTB4 leukotriene B4, (5S,6Z,8E,10E,12R,14Z)-5,12-dihydroxyicosa6,8,10,14-tetraenoic acid; LTC4 leukotriene C4, $(5 S, 6 R, 7 E, 9 E, 11 Z, 14 Z)-6$ - $[(2 R)$-2-[[(4S)-4-amino-4-carboxybutanoyl]amino]-3(carboxymethylamino)-3-oxopropyl]sulfanyl-5-hydroxyicosa-7,9,11,14-tetraenoic acid; LTD4 leukotriene D4, (5S,6R,7E,9E,11Z, 14Z)-6-[(2R)-2-amino-3-(carboxymethylamino)-3-oxopropyl] sulfanyl-5-hydroxyicosa-7,9,11,14-tetraenoic acid; LTE4 leukotriene E4, (5S,6R,7E,9E,11Z,14Z)-6-[(2R)-2-amino-2-carboxyethyl]sulfanyl-5-hydroxyicosa-7,9,11,14-tetraenoic acid; 5-oxo-ETE (6E, 8Z,11Z,14Z)-5-oxoicosa-6,8,11,14-tetraenoic acid; Cox cyclooxygenase; Cox-1 cyclooxygenase 1; Cox-2 cyclooxygenase 2; Cox-3 isoform of Cox-2 (therefore in brakes); PGG2 prostaglandin G2, (Z)-7-[(1S,4R,5R,6R)-5-[(E,3S)-3-hydroperoxyoct-1-enyl]-2,3dioxabicyclo[2.2.1]heptan-6-yl]hept-5-enoic acid; PGH2 prostaglandin H2, $(Z)-7$-[(1S,4R,5R,6R)-5-[(E,3S)-3-hydroxyoct-1-enyl]2,3-dioxabicyclo[2.2.1]heptan-6-yl]hept-5-enoic acid; PGFF2 $\boldsymbol{\alpha}$ prostaglandine F2 alpha, (Z)-7-[(1R,2R,3R,5S )-3,5-dihydroxy-2[(E,3S)-3-hydroxyoct-1-enyl]cyclopentyl]hept-5-enoic acid; PGD2 prostaglandin D2, $(Z)$-7-[(1R,2R,5S)-5-hydroxy-2-[(E,3S)-3hydroxyoct-1-enyl]-3-oxocyclopentyl|hept-5-enoic acid; PGE2 prostaglandin E2, $(Z)$-7-[(1R,2R,3R)-3-hydroxy-2-[( $E, 3 S)$-3-hydroxyoct-1-enyl]-5-oxocyclopentyl]hept-5-enoic acid; MDA malondialdehyde, propanedial; TXA2 thromboxane A2, $(Z)-7-[(1 S$, $2 S, 3 R, 5 S)$-3-[(E,3S)-3-hydroxyoct-1-enyl]-4,6-dioxabicyclo[3.1.1]heptan-2-yl]hept-5-enoic acid; CYP* cytochrome P450 isoforms; 20-OH-PGE2 20-hydroxy prostaglandin E2; 20-HETE 20-hydroxyeicosatetraenoic acid, (5Z,8Z,11Z,14Z)-20-hydroxyicosa5,8,11,14-tetraenoic acid; SOX [sex-determining region Y (Sry) box-containing] transcription factor family; IL- $\boldsymbol{\beta} 1$ interleukin beta 1; IL-33 interleukin 33; ROS reactive oxygen species; CXC CC chemokine receptors; $\boldsymbol{\alpha}$ SMAD alpha-smooth muscle actin; miR21 
The lipogenic enzyme, acetyl-CoA carboxylase 1 (ACC1), has a central function in fatty acid synthesis $[162,163]$. Inhibition of ACC1 occurs by phosphorylation induced by leptin and mediated through transforming growth factor beta (TGF- $\beta$ ) signaling by activating TGF$\beta$-activated kinase 1 (TAK1). This enzymatic reaction results in the elevation of Smad2 transcription factor acetylation and activation, resulting in cell transition and metastases in mice. Inactive ACC1 levels were found to be increased in metastatic human breast cancer while inhibiting leptin reduced metastasis [164]. This is in accordance with the finding that leptin itself triggers metastasis in A549 lung cancer cells in vitro [165]. As leptin and TGF are increased in obese individuals [166-169], ACC1 can be inactivated during chronic inflammation.

It has recently been shown that lysyl oxidase is increased in morbidly obese patients [170]. This results in an ongoing stimulation of multiple pathways illustrated in Fig. 1. It is known that there is a negative leptin/TGF- $\beta$ signaling loop [170,171], but leptin was shown to augment signaling in lung fibroblasts by inhibiting the inhibitor of the transcriptional response to TGF- $\beta 1$ via inhibition of peroxisome proliferator-activated receptor- $\gamma$ (PPAR $\gamma$ ) [172]. This again shows that here also disruption of homeostasis plays a key early role in carcinogenesis. Furthermore, leptin induces cell proliferation and inhibits apoptosis in human hepatocellular carcinoma (HCC) via promotion of Cyclin D1 and Bax/Janus-kinase-2 signaling [173].

The influence of the composition of the microbiome in cancer patients shows that it influences cancer progression and may well play a role in cancer therapy as is illustrated by the metastatic melanoma data [37]. An increased gut bacterial diversity was associated with decreased progression and improved progression-free survival (PFS). Patients with enriched Ruminococcaceae family were associated with responders to immunotherapy, while nonresponders showed a higher composition with Bacteroidales. Abundance of Faecalibacterium revealed prolonged PFS, while Bacteroidales abundance was associated with more rapid disease progression and decreased PFS. Furthermore, enriched Ruminococcaceae family showed higher levels of circulating $\mathrm{T}$ cells, while
Bacteroidales abundance showed lower circulating regulatory $\mathrm{T}$ cells, myeloid derived suppressor cells, and a blunted cytokine response.

Inoculating commercial broiler chickens with infectious bursal disease high virulent strain vvIBDV strain $89163 / 7.3$ resulted into a change of the gut microbiome composition with abundance of Clostridium XIVa and Faecalibacterium compared to virus-free birds indicating an impact to gut-associated lymphoid tissues [174]. Therefore, it was suggested that after the acute phase, gut-associated lymphoid tissue could be modulated by dysregulation of gut mucosal immunity. CRC [175] and IBD [176] are associated with abundance of Faecalibacterium prausnitzii (reviewed in [174]). These findings may impact future virus infection research and its influence on reservoir species, as well as on microbiome and chronic inflammation.

\section{Summary}

The microbial ecology has huge impact on life, evolution, as well as pathogenic stimuli on the development on cancer. The interplay of pathogenic stimuli with consequent chronic inflammation [8,9], proteins [177], and the release of cytokines from many cell types provide a micromilieu promoting the PCN (Fig. 1). The complexity of dysregulated homeostasis increases when one considers the microbiome, high-fat diet, and morbid obesity [178]. The microbial flora itself can increase obesity. The effects of changes in the composition of such symbionts in humans on signaling pathways and induced crosstalk are appreciable and influence metabolism and signaling pathways in various ways triggering chronic inflammation, cell proliferation, and the inhibition of apoptosis. Even pathogenic viral stimuli influence gut-associated lymphoid tissue to modulate the microbiome composition. Pathogenic stimuli, with its consequent chronic inflammation, and the interplay of ubiquitous proteins, corresponding enzymes, and eicosanoids are influenced by the microbiome and morbid obesity resulting in the "Disruption of signaling homeostasis induced crosstalk in the carcinogenesis paradigm Epistemology of the origin of cancer." Remodeled fibrosis results in another prerequisite for the development of cancer (carcinogenesis) - the PCN.

micro RNA-21; p300 protein 300 (p300-CBP coactivator family); SP1 specificity protein 1; AP1 activator protein 1; E2F4/5 cytoplasmic complex of Smad3, retinoblastoma-like protein 1 (P107, RBL1), E2F4/5 and d-prostanoid (DP1); p107 retinoblastomalike protein 1, RBL1; TGFß transforming growth factor beta; Pro-MMP-9 pro-matrix metalloproteinase 9; Pro-MMP-1 promatrix metalloproteinase 1; Pro-MMP-7 pro matrix metalloproteinase 7; SNAIL zinc finger protein SNAI1; MMP-1 matrix metalloproteinase 1; MMP-7 matrix metalloproteinase 7; MMP-2 matrix metalloproteinase 2; E-Cadherin CAM $120 / 80$ or epithelial cadherin, cadherin-1, epithelial cadherin; CXCL1 chemokine (C-X-C motif) ligand 1; Osm oncostatin-M; PI3K phosphatidylinositide 3kinase; FOXO3a forkhead box protein O3a; p120 catenin delta-1, protein 120; Rho Ras homolog gene family, member A; Rac1 Rasrelated C3 botulinum toxin substrate 1; cdc42 cell division control protein 42 homolog; BIM Bcl-2 interacting mediator of cell death; PUMA BH3-only protein; CXCR4 C-X-C motif of chemokine receptor 4; cdk2 cyclin-dependent kinase 2; LOXL3 lysyl oxidase homolog $3 ; \mathbf{m T O R} 1$ rapamycin complex 1; PAI1 plasminogen activator inhibitor-1. 


\section{Nomenclature}

5-oxo-ETE

(6E,8Z,11Z,14Z)-5-oxoicosa-6,8,11,14tetraenoic acid

12-HETE

20-HETE

12-hydroxyeicosatetraenoic acid

20-hydroxyeicosatetraenoic acid,

$(5 Z, 8 Z, 11 Z, 14 Z)$-20-hydroxyicosa-

5,8,11,14-tetraenoic acid

20-OH-PGE2 20-hydroxy prostaglandin E2

$\alpha-\mathrm{MSH}$

$\alpha \mathrm{SMAD}$

ACC1

$\mathrm{AEY}$

Akt

ALOX

ALOX12

AP1

ASM

BAPN

BIM

BMI

CAG

$\operatorname{cdc} 42$

cdk2

Cox

Cox-1

Cox-2

Cox-3

CRC

CSES

CTL

$\mathrm{CYP}^{*}$

$\mathrm{CXC} \mathrm{CC}$

CXCL1

C-X-C

CXCR4

DAMP

$\mathrm{E} 2 \mathrm{~F} 4 / 5$

E-Cadherin

ECM

Erk1

Erk2

FADD

fFN

FGF-2

FLIP

alpha-smooth muscle actin

acetyl-CoA carboxylase 1

$\mathrm{N}$-arachidonoylethanolamine

(anandamide)

protein kinase $\mathrm{B}(=\mathrm{PKB})$

12-lipoxygenase, 12-LOX, 12S-LOX, activator protein 1

American Society of Microbiology

$\beta$-aminopropionitrile

body mass index

co-abundance group

cyclin-dependent kinase 2

cyclooxygenase

cyclooxygenase 1

cyclooxygenase 2

isoform of Cox-2 (therefore in brakes)

colorectal cancer

chronic stress escape strategy

C-type lectin

cytochrome $\mathrm{P} 450$ isoforms

chemokine receptors

chemokine ( $\mathrm{C}-\mathrm{X}-\mathrm{C}$ motif) ligand 1 ,

GRO $\alpha$, GRO1, MSGA- $\alpha$, NAP3

cytokine chemokine $(\mathrm{C}-\mathrm{X}-\mathrm{C}$ motif)

$\mathrm{C}-\mathrm{X}-\mathrm{C}$ motif of chemokine receptor 4

danger associated molecular patterns

E2F4/5 and d-prostanoid (DP1)

CAM 120/80 or epithelial cadherin,

cadherin-1, epithelial cadherin

extracellular matrix

mitogen-activated protein kinase 3 ,

MAPK3

mitogen-activated protein kinase 1 ,

MAPK1

fetal fibronectin

fibroblast growth factor-2
FOXO3a

FSP

Hsp70

gp130

GPRC5B

$\mathrm{GRO} \alpha$

GRO1

alpha melanocyte-stimulating hormone

lipoxygenase, arachidonate lipoxygenase arachidonate 12 -lipoxygenase $12 \mathrm{~S}$ type;

Bcl-2 interacting mediator of cell death

cell division control protein 42 homolog

GTP

$\mathrm{HCC}$

HMP

IBD

$\mathrm{IFN} \gamma$

IKK $\beta$

IL- $\beta 1$

IL-6

IL-8

IL-17

IL-33

JAK2

MMP-1

MMP-2

MMP-7

MMP-9

LOX5

LOXL3

LRR

LTA4

cytoplasmic complex of Smad3, retino-

blastoma-like protein 1 (P107, RBL1),

LTD4

LTE4

extracellular signal-regulated kinase 1,

MAPK

extracellular signal-regulated kinase 2, MAPK3

Fas-associated protein with death domain

CASP8 and Fas-associated protein with

death domain (FADD)-like apoptosis

regulator

MAPK7 forkhead box protein O3a

fibroblast secretory protein

heat shock protein 70

glycoprotein 130

$\mathrm{G}$ protein-coupled receptor family $\mathrm{C}$ group 5 member B

melanoma growth stimulating activity alpha, CXCL1, GRO1, MSGA- $\alpha$, NAP3

melanoma growth stimulating activity 1 , melanoma growth stimulating activity alpha, GRO $\alpha$, CXCL1, MSGA- $\alpha$, NAP3 guanosine- 5 -triphosphate

hepatocellular carcinoma

Human Microbiome Project

inflammatory bowel disease

interferon gamma

inhibitor of kappa B kinase beta

interleukin beta 1

interleukin 6

interleukin 8

interleukin 17

interleukin 33

Janus kinase 2

metalloproteinase 1

metalloproteinase 2

metalloproteinase 7

metalloproteinase 9

5-lipoxygenase, 5-LOX, arachidonate

5 -lipoxygenase

lysyl oxidase homolog 3

leucine rich repeat

leukotriene A4, 4-[(2S,3S)-3-

[(1E,3E,5Z,8Z)-tetradeca-1,3,5,8-tet-

raenyl oxiran-2-yl]butanoic acid

leukotriene B4, (5S,6Z,8E,10E,12R,14Z)-

5,12-dihydroxyicosa-6,8,10,14-tetraenoic acid

leukotriene $\mathrm{C} 4,(5 S, 6 R, 7 E, 9 E, 11 Z, 14 Z)-6$ [(2R)-2-[[(4S)-4-amino-4-carboxybutanoyl]amino]-3-(carboxymethylamino)-3oxopropyl] sulfanyl-5-hydroxyicosa-

7,9,11,14-tetraenoic acid

leukotriene $\mathrm{D} 4,(5 S, 6 R, 7 E, 9 E, 11 Z, 14 Z)$ -

6-[(2R)-2-amino-3-(carboxymethyla-

mino)-3-oxopropyl]sulfanyl-5-hydroxyi-

cosa-7,9,11,14-tetraenoic acid

leukotriene $\mathrm{E} 4,(5 S, 6 R, 7 E, 9 E, 11 Z, 14 Z)-6$ [(2R)-2-amino-2-carboxyethyl]sulfanyl-5hydroxyicosa-7,9,11,14-tetraenoic acid mitogen-activated protein kinase

mitogen-activated protein kinase 3,

extracellular signal-regulated kinase 1, Erk1

mitogen-activated protein kinase 7, extracellular signal-regulated kinase 5, Erk5 malondialdehyde, propanedial

micro RNA-21

matrix metalloproteinase 1

matrix metalloproteinase 2 


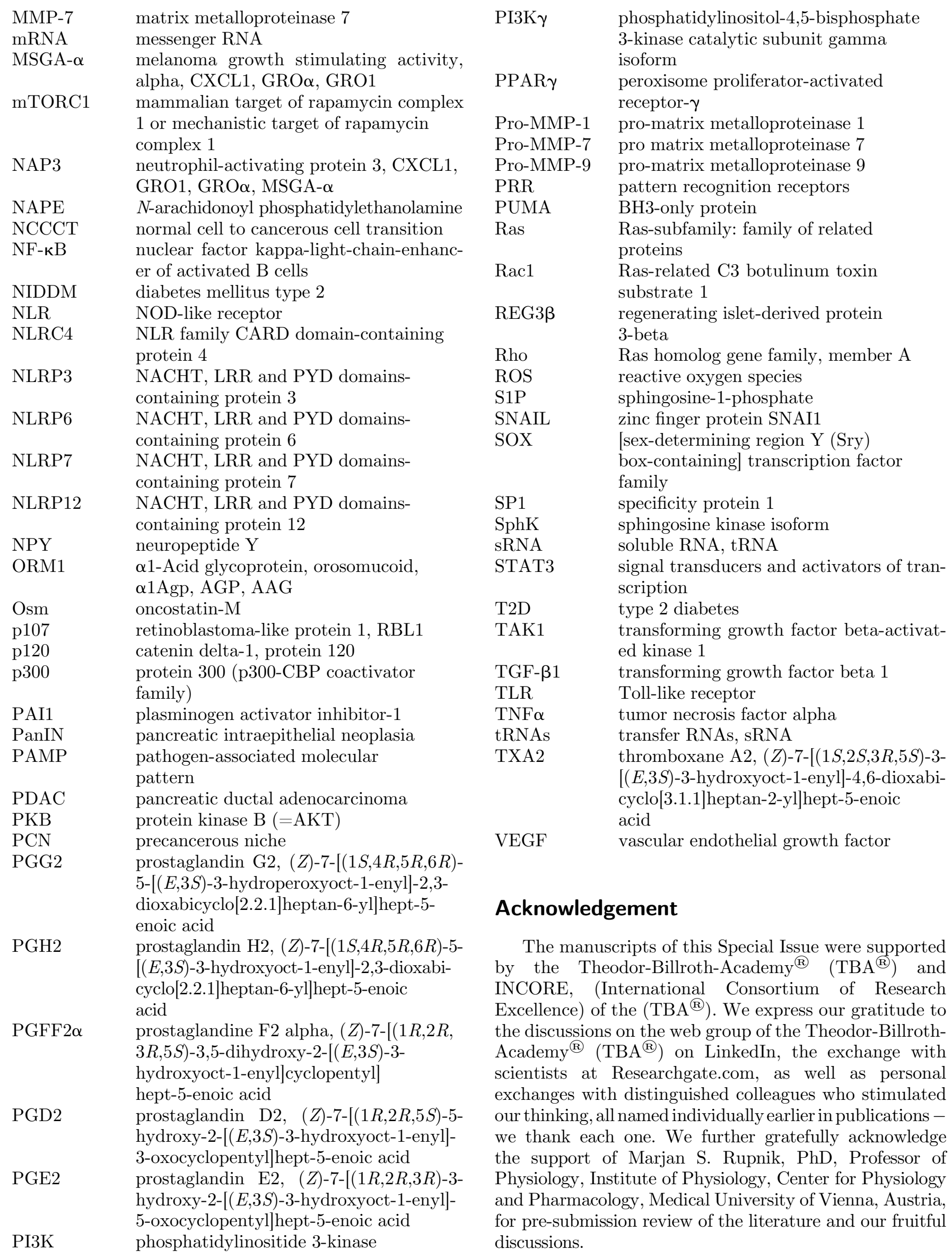




\section{Conflict of interest}

The author reports the following conflict of interest: Björn LDM Brücher is Editor-in-Chief in Life SciencesMedicine of 4open by EDP Sciences. Ijaz S. Jamall is Senior Editorial Board member in Life Sciences-Medicine of 4open by EDP Sciences. The authors, of their own initiative, suggested to the Managing Editorial to perform a transparent peer review of their submittals. Neither author took any action to influence the standard submission and peer-review process, and report no conflict of interest. The authors alone are responsible for the content and writing of the manuscript of this Special Issue. This manuscript contains original material that has not previously been published. Both authors contributed to the discussion on its contents and approved the manuscript.

\section{References}

1. Schaechter M, Kolter R, Buckley M (2004), Microbiology in the 21st century: where are we and where are we going? American Society for Microbiology, Washington, DC. Available at http://www.asm.org/Academy/index.asp? bidp29245

2. Spellberg B, Guidos R, Gilbert D, Bradley J, Boucher HW, Scheld WM, Bartlett JG, Edwards J, Jr, Infectious Diseases Society of America (2008), The epidemic of antibiotic-resistant infections: a call to action for the medical community from the Infectious Diseases Society of America. Clin Infect Dis 46, 155-164.

3. Rodrigues Hoffmann A, Proctor LM, Surette MG, Suchodolski JS (2016), The microbiome: the trillions of microorganisms that maintain health and cause disease in humans and companion animals. Vet Pathol 53, 10-21.

4. Tjalsma H, Boleij A, Marchesi JR, Dutilh BE (2012), A bacterial driver-passenger model for colorectal cancer: beyond the usual suspects. Nat Rev Microbiol 10, 575-582.

5. Sender R, Fuchs S, Milo R (2016), Revised estimates for the number of human and bacteria cells in the body. PLoS Biol 14, e1002533.

6. Savage DC (1977), Microbial ecology of the gastrointestinal tract. Annu Rev Microbiol 31, 107-133.

7. Ley RE, Turnbaugh PJ, Klein S, Gordon JI (2006), Microbial ecology: human gut microbes associated with obesity. Nature 444, 1022-1023.

8. Brücher BLDM, Jamall IS (2019), Chronic inflammation evoked by pathogenic stimulus during carcinogenesis. 4open 2, 8, 1-22. https://doi.org/10.1051/fopen/2018006

9. Brücher BLDM, Jamall IS (2019), Eicosanoids in carcinogenesis. 4open 2, 9, 1-34. https://doi.org/10.1051/fopen/ 2018008

10. Mishima E, Sharma A (2011), Tannerella forsythia invasion in oral epithelial cells requires phosphoinositide 3-kinase activation and clathrin-mediated endocytosis. Microbiology 157, 2382-2391.

11. Honma K, Mishima E, Sharma A (2011), Role of Tannerella forsythia NanH sialidase in epithelial cell attachment. Infect Immun 79, 393-401.

12. Wu JS, Zheng M, Zhang M, Pang X, Li L, Wang SS, Yang X, Wu JB, Tang YJ, Tang YL, Liang XH (2018), Porphyromonas gingivalis promotes 4-nitroquinoline-1-oxide-induced oral carcinogenesis with an alteration of fatty acid metabolism. Front Microbiol 9, 2081.
13. Binder Gallimidi A, Fischman S, Revach B, Bulvik R, Maliutina A, Rubinstein AM, Nussbaum G, Elkin M (2015), Periodontal pathogens Porphyromonas gingivalis and Fusobacterium nucleatum promote tumor progression in an oral-specific chemical carcinogenesis model. Oncotarget 6, 22613-22623.

14. Snider EJ, Freedberg DE, Abrams JA (2016), Potential role of the microbiome in Barrett's esophagus and esophageal adenocarcinoma. Dig Dis Sci 61, 2217-2225.

15. Peters BA, Wu J, Pei Z, Yang L, Purdue MP, Freedman ND, Jacobs EJ, Gapstur SM, Hayes RB, Ahn J (2017), Oral microbiome composition reflects prospective risk for esophageal cancers. Cancer Res 77, 6777-6787.

16. Michaud DS, Izard J, Wilhelm-Benartzi CS, You DH, Grote VA, Tjønneland A, Dahm CC, Overvad K, Jenab M, Fedirko V, Boutron-Ruault MC, Clavel-Chapelon F, Racine A, Kaaks R, Boeing H, Foerster J, Trichopoulou A, Lagiou P, Trichopoulos D, Sacerdote C, Sieri S, Palli D, Tumino R, Panico S, Siersema PD, Peeters PH, Lund E, Barricarte A, Huerta JM, Molina-Montes E, Dorronsoro M, Quirós JR, Duell EJ, Ye W, Sund M, Lindkvist B, Johansen D, Khaw KT, Wareham N, Travis RC, Vineis P, Bueno-de-Mesquita HB, Riboli E (2013), Plasma antibodies to oral bacteria and risk of pancreatic cancer in a large European prospective cohort study. Gut 62 , 1764-1770.

17. Ögrendik M (2017), Periodontal Pathogens in the Etiology of Pancreatic Cancer. Gastrointest Tumors 3, 125-127.

18. Lu H, Ren Z, Li A, Zhang H, Jiang J, Xu S, Luo Q, Zhou K, Sun X, Zheng S, Li L (2016), Deep sequencing reveals microbiota dysbiosis of tongue coat in patients with liver carcinoma. Sci Rep 6, 33142 .

19. Honma K, Ruscitto A, Sharma A (2017), $\beta$-Glucanase activity of the oral bacterium Tannerella forsythia contributes to the growth of a partner species, Fusobacterium nucleatum, in co-biofilms. Appl Environ Microbiol pii, AEM. 01759-17.

20. Yu J, Chen Y, Fu X, Zhou X, Peng Y, Shi L, Chen T, Wu Y (2016), Invasive Fusobacterium nucleatum may play a role in the carcinogenesis of proximal colon cancer through the serrated neoplasia pathway. Int J Cancer 139, 1318-1326.

21. Farhana L, Antaki F, Murshed F, Mahmud H, Judd SL, Nangia-Makker P, Levi E, Yu Y, Majumdar AP (2018), Gut microbiome profiling and colorectal cancer in African Americans and Caucasian Americans. World J Gastrointest Pathophysiol 9, 47-58.

22. Liu Y, Baba Y, Ishimoto T, Iwatsuki M, Hiyoshi Y, Miyamoto Y, Yoshida N, Wu R, Baba H (2018), Progress in characterizing the linkage between Fusobacterium nucleatum and gastrointestinal cancer. J Gastroenterol. DOI: $10.1007 / \mathrm{s} 00535-018-1512-9$

23. Ding T, Schloss PD (2014), Dynamics and associations of microbial community types across the human body. Nature 509, 357-360.

24. Schirmer M, Smeekens SP, Vlamakis H, Jaeger M, Oosting M, Franzosa EA, Jansen T, Jacobs L, Bonder MJ, Kurilshikov A, Fu J, Joosten LA, Zhernakova A, Huttenhower C, Wijmenga C, Netea MG, Xavier RJ (2016), Linking the human gut microbiome to inflammatory cytokine production capacity. Cell 167, 11251136.

25. Waki M, Ide Y, Ishizaki I, Nagata Y, Masaki N, Sugiyama E, Kurabe N, Nicolaescu D, Yamazaki F, Hayasaka T, Ikegami K, Kondo T, Shibata K, Hiraide T, Taki Y, Ogura H, Shiiya N, Sanada N, Setou M (2014), Single-cell timeof-flight secondary ion mass spectrometry reveals that 
human breast cancer stem cells have significantly lower content of palmitoleic acid compared to their counterpart non-stem cancer cells. Biochimie 107, 73-77.

26. Chernet BT, Levin M (2013), Transmembrane voltage potential is an essential cellular parameter for the detection and control of tumor development in a Xenopus model. Dis Model Mech 6, 595-607.

27. Brücher BLDM, Jamall IS (2014), Epistemology of the origin of cancer: a new paradigm. BMC Cancer 14, $1-15$.

28. Ferreira R, Oliveira $P$, Martins T, Magalhães S, Trindade F, Pires MJ, Colaço B, Barros A, Santos L, Amado F, Vitorino R (2015), Comparative proteomic analyses of urine from rat urothelial carcinoma chemically induced by exposure to $N$-butyl- $N$-(4-hydroxybutyl)-nitrosamine. Mol Biosyst 11, 1594-1602.

29. Bernardo C, Cunha MC, Santos JH, da Costa JM, Brindley PJ, Lopes C, Amado F, Ferreira R, Vitorino R, Santos LL (2016), Insight into the molecular basis of Schistosoma haematobium-induced bladder cancer through urine proteomics. Tumour Biol 37, 11279-11287.

30. Messina CM, Pizzo F, Santulli A, Bušelić I, Boban M, Orhanović S, Mladineo I (2016), Anisakis pegreffi (Nematoda: Anisakidae) products modulate oxidative stress and apoptosis-related biomarkers in human cell lines. Parasit Vectors 9, 607.

31. Roche K, Feltus FA, Park JP, Coissieux MM, Chang C, Chan VBS, Bentires-Alj M, Booth BW (2017), Cancer cell redirection biomarker discovery using a mutual information approach. PLoS One 12, e0179265.

32. Xie L, Bourne PE (2015), Developing multi-target therapeutics to fine-tune the evolutionary dynamics of the cancer ecosystem. Front Pharmacol 6, 209.

33. Honda S, Loher P, Shigematsu M, Palazzo JP, Suzuki R, Imoto I, Rigoutsos I, Kirino Y (2016), Sex hormonedependent tRNA halves enhance cell proliferation in breast and prostate cancers. Proc Natl Acad Sci USA 112, E3816- E3825.

34. Baudrimont A, Voegeli S, Viloria EC, Stritt F, Lenon M, Wada T, Jaquet V, Becskei A (2017), Multiplexed gene control reveals rapid mRNA turnover. Sci Adv 3, e1700006.

35. Christ A, Günther P, Lauterbach MAR, Duewell P, Biswas D, Pelka K, Scholz CJ, Oosting M, Haendler K, Baßler K, Klee K, Schulte-Schrepping J, Ulas T, Moorlag SJCFM, Kumar V, Park MH, Joosten LAB, Groh LA, Riksen NP, Espevik T, Schlitzer A, Li Y, Fitzgerald ML, Netea MG, Schultze JL, Latz E (2018), Western diet triggers NLRP3-dependent innate immune reprogramming. Cell 2018 172, 162-175.

36. Albenberg LG, Wu GD (2014), Diet and the intestinal microbiome: associations, functions, and implications for health and disease. Gastroenterology 146, 1564-1572.

37. Gopalakrishnan V, Spencer CN, Nezi L, Reuben A, Andrews MC, Karpinets TV, Prieto PA, Vicente D, Hoffman K, Wie SC, Cogdill AP, Zhao L, Hudgens CW, Hutchinson DS, Manzo T, Petaccia de Macedo M, Cotechini T, Kumar T, Chen WS, Reddy SM, Szczepaniak Sloane R, Galloway-Pena J, Jiang H, Chen PL, Shpall EJ, Rezvani K, Alousi AM, Chemaly RF, Shelburne S, Vence LM, Okhuysen PC, Jensen VB, Swennes AG, McAllister F, Marcelo Riquelme Sanchez E, Zhang Y, Le Chatelier E, Zitvogel L, Pons N, Austin-Breneman JL, Haydu LE, Burton EM, Gardner JM, Sirmans E, Hu J, Lazar AJ, Tsujikawa T, Diab A, Tawbi H, Glitza IC, Hwu WJ, Patel SP, Woodman SE, Amaria RN, Davies MA, Gershenwald
JE, Hwu P, Lee JE, Zhang J, Coussens LM, Cooper ZA, Futreal PA, Daniel CR, Ajami NJ, Petrosino JF, Tetzlaff MT, Sharma P, Allison JP, Jenq RR, Wargo JA (2017), Gut microbiome modulates response to anti-PD-1 immunotherapy in melanoma patients. Science. DOI: 10.1126/ science.aan 4236

38. Kumar H, Kawai T, Akira S (2011), Pathogen recognition by the innate immune system. Int Rev Immunol 30, $16-34$.

39. Martinon F, Tschopp J (2005), NLRs join TLRs as innate sensors of pathogens. Trends Immunol 26, 447-454.

40. Fritz JH, Ferrero RL, Philpott DJ, Girardin SE (2006), Nod-like proteins in immunity, inflammation and disease. Nat Immunol 7, 1250-1257.

41. Schroder K, Tschopp J (2010), The inflammasomes. Cell 140, 821-832.

42. Pinheiro AS, Eibl C, Ekman-Vural Z, Schwarzenbacher R, Peti W (2011), The NLRP12 pyrin domain: structure, dynamics, and functional insights. J Mol Biol 413, 790-803.

43. Gharagozloo M, Mahvelati TM, Imbeault E, Gris P, Zerif E, Bobbala D, Ilangumaran S, Amrani A, Gris D (2015), The nod-like receptor, Nlrp12, plays an anti-inflammatory role in experimental autoimmune encephalomyelitis. J Neuroinflammation 12, 198.

44. Allen IC, Wilson JE, Schneider M, Lich JD, Roberts RA, Arthur JC, Woodford RM, Davis BK, Uronis JM, Herfarth HH, Jobin C, Rogers AB, Ting JP (2012), NLRP12 suppresses colon inflammation and tumorigenesis through the negative regulation of noncanonical NF- $\mathrm{kB}$ signaling. Immunity 36, 742-754.

45. Chen L, Wilson JE, Koenigsknecht MJ, Chou WC, Montgomery SA, Truax AD, Brickey WJ, Packey CD, Maharshak N, Matsushima GK, Plevy SE, Young VB, Sartor RB, Ting JP (2017), NLRP12 attenuates colon inflammation by maintaining colonic microbial diversity and promoting protective commensal bacterial growth. Nat Immunol 18, 541-551.

46. Truax AD, Chen L, Tam JW, Cheng N, Guo H, Koblansky AA, Chou WC, Wilson JE, Brickey WJ, Petrucelli A, Liu R, Cooper DE, Koenigsknecht MJ, Young VB, Netea MG, Stienstra R, Sartor RB, Montgomery SA, Coleman RA, Ting JP (2018), The inhibitory innate immune sensor NLRP12 maintains a threshold against obesity by regulating gut microbiota homeostasis. Cell Host Microbe 24, 364-378.

47. Zaki MH, Vogel P, Malireddi RK, Body-Malapel M, Anand PK, Bertin J, Green DR, Lamkanfi M, Kanneganti TD (2011), The NOD-like receptor NLRP12 attenuates colon inflammation and tumorigenesis. Cancer Cell 20, 649-660.

48. Flemer B, Lynch DB, Brown JM, Jeffery IB, Ryan FJ, Claesson MJ, O'Riordain M, Shanahan F, O'Toole PW (2017), Tumour-associated and non-tumour-associated microbiota in colorectal cancer. Gut 66, 633-643.

49. Omar Al-Hassi H, Ng O, Brookes M (2018), Tumourassociated and non-tumour-associated microbiota in colorectal cancer. Gut 67, 395.

50. Flemer B, Herlihy M, O'Riordain M, Shanahan F, O'Toole PW (2018), Tumour-associated and nontumour-associated microbiota: addendum. Gut Microbes 9, 369-373.

51. Flemer B, Warren RD, Barrett MP, Cisek K, Das A, Jeffery IB, Hurley E, O'Riordain M, Shanahan F, O'Toole PW (2018), The oral microbiota in colorectal cancer is distinctive and predictive. Gut 67, 1454-1463. 
52. Mendonça LABM, Dos Santos Ferreira R, de Cássia Avellaneda Guimarães R, de Castro AP, Franco OL, Matias R, Carvalho CME (2018), The complex puzzle of interactions among functional food, gut microbiota, and colorectal cancer. Front Oncol 8, 325.

53. Wu M, Wu Y, Li J, Bao Y, Guo Y, Yang W (2018), The dynamic changes of gut microbiota in Muc2 deficient mice. Int J Mol Sci 19, pii: E2809.

54. Zhang Y, Yu X, Yu E, Wang N, Cai Q, Shuai Q, Yan F, Jiang L, Wang H, Liu J, Chen Y, Li Z, Jiang Q (2018), Changes in gut microbiota and plasma inflammatory factors across the stages of colorectal tumorigenesis: a case-control study. BMC Microbiol 18, 92.

55. Haslam DW, James WP (2005), Obesity. Lancet 366, 1197-209.

56. Bradlow HL (2014), Obesity and the gut microbiome: pathophysiological aspects. Horm Mol Biol Clin Investig $17,53-61$.

57. Schulz MD, Atay C, Heringer J, Romrig FK, Schwitalla S, Aydin B, Ziegler PK, Varga J, Reindl W, Pommerenke C, Salinas-Riester G, Böck A, Alpert C, Blaut M, Polson SC, Brandl L, Kirchner T, Greten FR, Polson SW, Arkan MC (2014), High-fat-diet-mediated dysbiosis promotes intestinal carcinogenesis independently of obesity. Nature 514, 508-512.

58. Keith SW, Redden DT, Katzmarzyk PT, Boggiano MM, Hanlon EC, Benca RM, Ruden D, Pietrobelli A, Barger JL, Fontaine KR, Wang C, Aronne LJ, Wright SM, Baskin M, Dhurandhar NV, Lijoi MC, Grilo CM, DeLuca M, Westfall AO, Allison DB (2006), Putative contributors to the secular increase in obesity: exploring the roads less traveled. Int J Obes (Lond) 30, 1585-1594.

59. Farooqi S, O'Rahilly S (2006), Genetics and obesity in humans. Endocr Rev 27, 710-718.

60. DuPan RC, Golay A (2014), The obesity paradox. Rev Med Suiss 10, 1413-1417.

61. Kopple JD, Zhu X, Lew NL, Lowrie EG (1999), Body weight-for-height relationships predict mortality in maintenance hemodialysis patients. Kidney Int 56, 1136-1148.

62. Kalantar-Zadeh K, Block G, Humphreys MH, Kopple JD (2003), Reverse epidemiology of cardiovascular risk factors in maintenance dialysis patients. Kidney Int 63, 793-808.

63. Kern PA, Ranganathan S, Li C, Wood L, Ranganathan G (2001), Adipose tissue tumor necrosis factor and interleukin-6 expression in human obesity and insulin resistance. Am J Physiol Endocrinol Metab 280, E745- E751.

64. Xu H, Barnes GT, Yang Q, Tan G, Yang D, Chou CJ, Sole J, Nichols A, Ross JS, Tartaglia LA, Chen H (2003), Chronic inflammation in fat plays a crucial role in the development of obesity-related insulin resistance. J Clin Invest 112, 1821-1830.

65. Weisberg SP, McCann D, Desai M, Rosenbaum M, Leibel RL, Ferrante AW, Jr (2003), Obesity is associated with macrophage accumulation in adipose tissue. J Clin Invest 112, 1796-1808.

66. Subbaramaiah K, Morris PG, Zhou XK, Morrow M, Du B, Giri D, Kopelovich L, Hudis CA, Dannenberg AJ (2012), Increased levels of COX-2 and prostaglandin E2 contribute to elevated aromatase expression in inflamed breast tissue of obese women. Cancer Discov 2, 356-365.

67. Küper MA, Kratt T, Kramer KM, Zdichavsky M, Schneider JH, Glatzle J, Stüker D, Königsrainer A,
Brücher BLDM (2010), Effort, safety, and findings of routine preoperative endoscopic evaluation of morbidly obese patients undergoing bariatric surgery. Surg Endosc 24, 1996-2001.

68. Potter JD, Slattery ML, Bostick RM, Gapstur SM (1993), Colon cancer: a review of the epidemiology. Epidemiol Rev $15,499-545$.

69. Giovannucci E, Ascherio A, Rimm EB, Colditz GA, Stampfer MJ, Willett WC (1995), Physical activity, obesity, and risk for colon cancer and adenoma in men. Ann Intern Med 122, 327-334.

70. Schoen RE, Tangen CM, Kuller LH, Burke GL, Cushman M, Tracy RP, Dobs A, Savage PJ (1999), Increased blood glucose and insulin, body size, and incident colorectal cancer. J Natl Cancer Inst 91, 1147-1154.

71. Sass DA, Schoen RE, Weissfeld JL, Weissfeld L, Thaete FL, Kuller LH, McAdams M, Lanza E, Schatzkin A (2004), Relationship of visceral adipose tissue to recurrence of adenomatous polyps. Am J Gastroenterol 99, 687-693.

72. Keum N, Lee DH, Kim R, Greenwood DC, Giovannucci EL (2005), Visceral adiposity and colorectal adenomas: dose-response meta-analysis of observational studies. Ann Oncol 26, 1101-1109.

73. Otake S, Takeda H, Suzuki Y, Fukui T, Watanabe S, Ishihama K, Saito T, Togashi H, Nakamura T, Matsuzawa Y, Kawata S (2005), Association of visceral fat accumulation and plasma adiponectin with colorectal adenoma: evidence for participation of insulin resistance. Clin Cancer Res 11, 3642-3646.

74. Sato Y, Nozaki R, Yamada K, Takano M, Haruma K (2009), Relation between obesity and adenomatous polyps of the large bowel. Dig Endosc 21, 154-157.

75. Yamaji T, Iwasaki M, Sasazuki S, Kurahashi N, Mutoh M, Yamamoto S, Suzuki M, Moriyama N, Wakabayashi K, Tsugane S (2009), Visceral fat volume and the prevalence of colorectal adenoma. Am J Epidemiol 170, $502-511$.

76. Nam SY, Kim BC, Han KS, Ryu KH, Park BJ, Kim HB, Nam BH (2010), Abdominal visceral adipose tissue predicts risk of colorectal adenoma in both sexes. Clin Gastroenterol Hepatol 8, 443-450, e1-e2.

77. Nimptsch K, Giovannucci E, Willett WC, Fuchs CS, Wei $\mathrm{EK}, \mathrm{Wu} \mathrm{K}$ (2011), Body fatness during childhood and adolescence, adult height, and risk of colorectal adenoma in women. Cancer Prev Res (Phila) 4, 1710-1718.

78. Kim BC, Shin A, Hong CW, Sohn DK, Han KS, Ryu KH, Park BJ, Nam JH, Park JW, Chang HJ, Choi HS, Kim J, Oh JH (2012), Association of colorectal adenoma with components of metabolic syndrome. Cancer Causes Control 23, 727-735.

79. Summers RM, Liu J, Sussman DL, Dwyer AJ, Rehani B, Pickhardt PJ, Choi JR, Yao J (2012), Association between visceral adiposity and colorectal polyps on CT colonography. AJR Am J Roentgenol 199, 48-57.

80. Ashktorab H, Paydar M, Yazdi S, Namin HH, Sanderson A, Begum R, Semati M, Etaati F, Lee E, Brim H, Zenebe A, Nunlee-Bland G, Laiyemo AO, Nouraie M (2014), BMI and the risk of colorectal adenoma in African-Americans. Obesity (Silver Spring) 22, 1387-1391.

81. Nagata N, Sakamoto K, Arai T, Niikura R, Shimbo T, Shinozaki M, Aoki T, Kishida Y, Sekine K, Tanaka S, Okubo H, Watanabe K, Sakurai T, Yokoi C, Akiyama J, Yanase M, Noda M, Itoh T, Mizokami M, Uemura $\mathrm{N}$ (2014), Visceral abdominal fat measured by computed tomography is associated with an increased risk of colorectal adenoma. Int J Cancer 135, 2273-2281. 
82. Yamaji Y, Mitsushima T, Koike K (2014), Pulse-wave velocity, the ankle-brachial index, and the visceral fat area are highly associated with colorectal adenoma. Dig Liver Dis 46, 943-949.

83. Park JH, Kim SJ, Hyun JH, Han KS, Kim BC, Hong CW, Lee SJ, Sohn DK (2017), Correlation between bowel preparation and the adenoma detection rate in screening colonoscopy. Ann Coloproctol 33, 93-98.

84. Seo IK, Kim BJ, Kim B, Choi CH, Kim JW, Kim JG, Chang SK, Kang H (2017), Abdominal fat distribution measured using computed tomography is associated with an increased risk of colorectal adenoma in men. Medicine (Baltimore) 96, e8051.

85. Shapero TF, Chen GI, Devlin T, Gibbs A, Murray IC, Tran S, Weigensberg C (2017), Obesity increases prevalence of colonic adenomas at screening colonoscopy: a Canadian community-based study. Can J Gastroenterol Hepatol 2017, 8750967.

86. Im JP, Kim D, Chung SJ, Jin EH, Han YM, Park MJ, Song JH, Yang SY, Kim YS, Yim JY, Lim SH, Kim JS (2018), Visceral obesity as a risk factor for colorectal adenoma occurrence in surveillance colonoscopy. Gastrointest Endosc 88, 119-127, e4.

87. Friedman GD, Herrinton LJ (1994), Obesity and multiple myeloma. Cancer Causes Control 5, 479-483.

88. Brown LM, Gridley G, Pottern LM, Baris D, Swanso CA, Silverman DT, Hayes RB, Greenberg RS, Swanson GM, Schoenberg JB, Schwartz AG, Fraumeni JF, Jr (2001), Diet and nutrition as risk factors for multiple myeloma among blacks and whites in the United States. Cancer Causes Control 12, 117-125.

89. Thompson MA, Kyle RA, Melton LJ 3rd, Plevak MF, Rajkumar SV (2004), Effect of statins, smoking and obesity on progression of monoclonal gammopathy of undetermined significance: a case-control study. Haematologica 89, 626-628.

90. Alexander DD, Mink PJ, Adami HO, Cole P, Mandel JS, Oken MM, Trichopoulos D (2007), Multiple myeloma: a review of the epidemiologic literature. Int J Cancer 120, $40-61$.

91. Birmann BM, Giovannucci E, Rosner B, Anderson KC, Colditz GA (2007), Body mass index, physical activity, and risk of multiple myeloma. Cancer Epidemiol Biomarkers Prev 16, 1474-1478.

92. Larsson SC, Wolk A (2007), Body mass index and risk of multiple myeloma: a meta-analysis. Int J Cancer 121, $2512-2516$.

93. Landgren O, Rajkumar SV, Pfeiffer RM, Kyle RA, Katzmann JA, Dispenzieri A, Cai Q, Goldin LR, Caporaso NE, Fraumeni JF, Blot WJ, Signorello LB (2010), Obesity is associated with an increased risk of monoclonal gammopathy of undetermined significance among black and white women. Blood 116, 1056-1059.

94. Lichtman MA (2010), Obesity and the risk for a hematological malignancy: leukemia, lymphoma, or myeloma. Oncologist 15, 1083-1101.

95. Lwin ST, Olechnowicz SW, Fowler JA, Edwards CM (2015), Diet-induced obesity promotes a myeloma-like condition in vivo. Leukemia 29, 507-510.

96. Chang SH, Luo S, Thomas TS, O'Brian KK, Colditz GA, Carlsson NP, Carson KR (2016), Obesity and the transformation of monoclonal gammopathy of undetermined significance to multiple myeloma: a populationbased cohort study. J Natl Cancer Inst 109. DOI: 10.1093/ jnci/djw264

97. Sonderman JS, Bethea TN, Kitahara CM, Patel AV, Harvey C, Knutsen SF, Park Y, Park SY, Fraser GE,
Teras LR, Purdue MP, Stolzenberg-Solomon RZ, Gillanders EM, Palmer JR, Kolonel LN, Blot WJ (2016), Multiple myeloma mortality in relation to obesity among African Americans. J Natl Cancer Inst 108, pii: djw 120 .

98. Thordardottir M, Lindqvist EK, Lund SH, Costello R, Burton D, Korde N, Mailankody S, Eiriksdottir G, Launer LJ, Gudnason V, Harris TB, Landgren O, Kristinsson SY (2017), Obesity and risk of monoclonal gammopathy of undetermined significance and progression to multiple myeloma: a population-based study. Blood Adv 1, 2186-2192.

99. Brunicardi FC, Chaiken RL, Ryan AS, Seymour NE, Hoffmann JA, Lebovitz HE, Chance RE, Gingerich RL, Andersen DK, Elahi D (1996), Pancreatic polypeptide administration improves abnormal glucose metabolism in patients with chronic pancreatitis. J Clin Endocrinol Metab 81, 3566-3572.

100. Gumbs AA (2008), Obesity, pancreatitis, and pancreatic cancer. Obes Surg 18, 1183-1187.

101. Eibl G, Cruz-Monserrate Z, Korc M, Petrov MS, Goodarzi MO, Fisher WE, Habtezion A, Lugea A, Pandol SJ, Hart PA, Andersen DK; Consortium for the Study of Chronic Pancreatitis, Diabetes, and Pancreatic Cancer (2018), Diabetes mellitus and obesity as risk factors for pancreatic cancer. J Acad Nutr Diet 118, $555-567$.

102. Melitas C, Meiselman M (2018), Metabolic pancreatitis: pancreatic steatosis, hypertriglyceridemia, and associated chronic pancreatitis in 3 patients with metabolic syndrome. Case Rep Gastroenterol 12, $331-336$.

103. Karmiris K, Koutroubakis IE, Kouroumalis EA (2005), The emerging role of adipocytokines as inflammatory mediators in inflammatory bowel disease. Inflamm Bowel Dis 11, 847-855.

104. John BJ, Abulafi AM, Poullis A, Mendall MA (2007), Chronic subclinical bowel inflammation may explain increased risk of colorectal cancer in obese people. Gut $56,1034-1035$.

105. Tilg H, Moschen AR (2008), Role of adiponectin and $\mathrm{PBEF} /$ visfatin as regulators of inflammation: involvement in obesity-associated diseases. Clin Sci (Lond) 114, 275-288.

106. Kreuter R, Wankell M, Ahlenstiel G, Hebbard L (2018), The role of obesity in inflammatory bowel disease. Biochim Biophys Acta Mol Basis Dis 1865, 63-72.

107. Chen S, Chen CM, Zhou Y, Zhou RJ, Yu KD, Shao ZM (2012), Obesity or overweight is associated with worse pathological response to neoadjuvant chemotherapy among Chinese women with breast cancer. PLoS One 7, e41380.

108. Robinson PJ, Bell RJ, Davis SR (2014), Obesity is associated with a poorer prognosis in women with hormone receptor positive breast cancer. Maturitas 79, 279-286.

109. Seo BR, Bhardwaj P, Choi S, Gonzalez J, Andresen Eguiluz RC, Wang K, Mohanan S, Morris PG, Du B, Zhou XK, Vahdat LT, Verma A, Elemento O, Hudis CA, Williams RM, Gourdon D, Dannenberg AJ, Fischbach C (2015), Obesity-dependent changes in interstitial ECM mechanics promote breast tumorigenesis. Sci Transl Med 7, 301ra130.

110. Gravena AAF, Romeiro Lopes TC, Demitto MO, Borghesan DHP, Dell' Agnolo CM, Brischiliari SCR, Carvalho MDB, Pelloso SM (2018), The obesity and the risk of breast cancer among pre and postmenopausal women. Asian Pac J Cancer Prev 19, 2429-2436. 
111. Nyasani E, Munir I, Perez M, Payne K, Khan S (2018), Linking obesity-induced leptin-signaling pathways to common endocrine-related cancers in women. Endocrine. DOI: $10.1007 / \mathrm{s} 12020-018-1748-4$

112. Tartter PI, Slater G, Papatestas AE, Aufses AH, Jr (1984), Cholesterol, weight, height, Quetelet's index, and colon cancer recurrence. J Surg Oncol 27, 232-235.

113. Dignam JJ, Polite BN, Yothers G, Raich P, Colangelo L, O'Connell MJ, Wolmark N (2006), Body mass index and outcomes in patients who receive adjuvant chemotherapy for colon cancer. J Natl Cancer Inst 98, 1647-1654.

114. Wu S, Liu J, Wang X, Li M, Gan Y, Tang Y (2014), Association of obesity and overweight with overall survival in colorectal cancer patients: a meta-analysis of 29 studies. Cancer Causes Control 25, 1489-1502.

115. Colussi D, Fabbri M, Zagari RM, Montale A, Bazzoli F, Ricciardiello L (2018), Lifestyle factors and risk for colorectal polyps and cancer at index colonoscopy in a FIT-positive screening population. United European Gastroenterol J 6, 935-942.

116. da Silva M, Weiderpass E, Licaj I, Lissner L, Rylander C (2018), Excess body weight, weight gain and obesityrelated cancer risk in women in Norway: the Norwegian Women and Cancer study. Br J Cancer 119, 646-656.

117. Mu N, Zhu Y, Wang Y, Zhang H, Xue F (2012), Insulin resistance: a significant risk factor of endometrial cancer. Gynecol Oncol 125, 751-757.

118. MacInnis RJ, English DR (2006), Body size and composition and prostate cancer risk: systematic review and meta-regression analysis. Cancer Causes Control 17, 989-1003.

119. Choi Y, Park B, Jeong BC, Seo SI, Jeon SS, Choi HY, Adami HO, Lee JE, Lee HM (2013), Body mass index and survival in patients with renal cell carcinoma: a clinicalbased cohort and meta-analysis. Int J Cancer 132, 625634.

120. Leo QJ, Ollberding NJ, Wilkens LR, Kolonel LN, Henderson BE, Le Marchand L, Maskarinec G (2014), Obesity and non-Hodgkin lymphoma survival in an ethnically diverse population: the Multiethnic Cohort study. Cancer Causes Control 25, 1449-1459.

121. Wienecke A, Neuhauser H, Kraywinkel K, Barnes B (2018), Cancers potentially preventable through excess weight reduction in Germany in 2010. Obes Facts 11, 400-412.

122. Geyer SM, Morton LM, Habermann TM, Allmer C, Davis S, Cozen W, Severson RK, Lynch CF, Wang SS, Maurer MJ, Hartge P, Cerhan JR (2010), Smoking, alcohol use, obesity, and overall survival from nonHodgkin lymphoma: a population-based study. Cancer 116, 2993-3000.

123. Jones JA, Fayad LE, Elting LS, Rodriguez MA (2010), Body mass index and outcomes in patients receiving chemotherapy for intermediate-grade B-cell non-Hodgkin lymphoma. Leuk Lymphoma 51, 1649-1657.

124. Carson KR, Bartlett NL, McDonald JR, Luo S, Zeringue A, Liu J, Fu Q, Chang SH, Colditz GA (2012), Increased body mass index is associated with improved survival in United States veterans with diffuse large B-cell lymphoma. J Clin Oncol 30, 3217-3222.

125. Han X, Stevens J, Bradshaw PT (2013), Body mass index, weight change, and survival in non-Hodgkin lymphoma patients in Connecticut women. Nutr Cancer $65,43-50$.

126. Gevers TJG, BWM, Veendrick PB, Vrolijk JM (2018), Regression of hepatocellular adenoma after bariatric surgery in severe obese patients. Liver Int. DOI: 10.1111/liv.13934
127. Incio J, Ligibel JA, McManus DT, Suboj P, Jung K, Kawaguchi K, Pinter M, Babykutty S, Chin SM, Vardam TD, Huang Y, Rahbari NN, Roberge S, Wang D, GomesSantos IL, Puchner SB, Schlett CL, Hoffmman U, Ancukiewicz M, Tolaney SM, Krop IE, Duda DG, Boucher Y, Fukumura D, Jain RK (2018), Obesity promotes resistance to anti-VEGF therapy in breast cancer by up-regulating IL-6 and potentially FGF-2. Sci Transl Med 10, pii: eaag 0945.

128. Hillers LE, D'Amato JV, Chamberlin T, Paderta G, Arendt LM (2018), Obesity-activated adipose-derived stromal cells promote breast cancer growth and invasion. Neoplasia 20, 1161-1174.

129. Benzler J, Ganjam GK, Pretz D, Oelkrug R, Koch CE, Legler K, Stöhr S, Culmsee C, Williams LM, Tups A (2015), Central inhibition of IKK $\beta / N F-\kappa B$ signaling attenuates high-fat diet-induced obesity and glucose intolerance. Diabetes 64, 2015-2027.

130. Wei X, Song H, Yin L, Rizzo MG, Sidhu R, Covey DF, Ory DS, Semenkovich CF (2016), Fatty acid synthesis configures the plasma membrane for inflammation in diabetes. Nature 539, 294-298.

131. Breasson L, Becattini B, Sardi C, Molinaro A, Zani F, Marone R, Botindari F, Bousquenaud M, Ruegg C, Wymann MP, Solinas G (2017), PI3K $\gamma$ activity in leukocytes promotes adipose tissue inflammation and early-onset insulin resistance during obesity. Sci Signal 10, eaaf 2969.

132. Kim YJ, Sano T, Nabetani T, Asano Y, Hirabayashi Y (2012), GPRC5B activates obesity-associated inflammatory signaling in adipocytes. Sci Signal 2012, 5, ra85.

133. Incio J, Liu H, Suboj P, Chin SM, Chen IX, Pinter M, Ng MR, Nia HT, Grahovac J, Kao S, Babykutty S, Huang Y, Jung K, Rahbari NN, Han X, Chauhan VP, Martin JD, Kahn J, Huang P, Desphande V, Michaelson J, Michelakos TP, Ferrone CR, Soares R, Boucher Y, Fukumura D, Jain RK (2016), Obesity-induced inflammation and desmoplasia promote pancreatic cancer progression and resistance to chemotherapy. Cancer Discov 6, 852-869.

134. Yang G, Rosen DG, Zhang Z, Bast RC Jr, Mills GB, Colacino JA, Mercado-Uribe I, Liu J (2006), The chemokine growth-regulated oncogene 1 (Gro-1) links RAS signaling to the senescence of stromal fibroblasts and ovarian tumorigenesis. Proc Natl Acad Sci USA 103, 16472-16477.

135. Richmond A, Lawson DH, Nixon DW, Chawla RK (1985), Characterization of autostimulatory and transforming growth factors from human melanoma cells. Cancer Res 45, 6390-6394.

136. Schludi B, Moin ASM, Montemurro C, Gurlo T, Matveyenko AV, Kirakossian D, Dawson DW, Dry SM, Butler PC, Butler AE (2017), Islet inflammation and ductal proliferation may be linked to increased pancreatitis risk in type 2 diabetes. JCI Insight 2, pii: 92282.

137. Loncle C, Bonjoch L, Folch-Puy E, Lopez-Millan EB, Lac S, Molejon MI, Chuluyan E, Cordelier P, Dubus P, Lomberk G, Urrutia R, Closa D, Iovanna JL (2015), IL-17 functions through the novel REG3 $\beta$-JAK2-STAT3 inflammatory pathway to promote the transition from chronic pancreatitis to pancreatic cancer. Cancer Res 75, 4852-4862.

138. Boncela, J, Papiewska I, Fijalkowska I, Walkowiak B, Cierniewski CS (2001), Acute phase protein alpha 1-acid glycoprotein interacts with plasminogen activator inhibitor type 1 and stabilizes its inhibitory activity. J Biol Chem 276, 35305-35311. 
139. Savetsky IL, Torrisi JS, Cuzzone DA, Ghanta S, Albano NJ, Gardenier JC, Joseph WJ, Mehrara BJ (2014), Obesity increases inflammation and impairs lymphatic function in a mouse model of lymphedema. Am J Physiol Heart Circ Physiol 307, H165-172.

140. Araldi RP, Módolo DG, de Sá Júnior PL, Consonni SR, de Carvalho RF, Roperto FP, Beçak W, de Cassia Stocco R (2016), Genetics and metabolic deregulation following cancer initiation: a world to explore. Biomed Pharmacother 82, 449-458.

141. Ekoff M, Kaufmann T, Engström M, Motoyama N, Villunger A, Jönsson JI, Strasser A, Nilsson G (2007), The BH3-only protein Puma plays an essential role in cytokine deprivation induced apoptosis of mast cells. Blood 110, 3209-3217.

142. Skurk C, Maatz H, Kim HS, Yang J, Abid MR, Aird WC, Walsh K (2004), The Akt-regulated forkhead transcription factor FOXO3a controls endothelial cell viability through modulation of the caspase- 8 inhibitor FLIP. J Biol Chem 279, 1513-1525.

143. Zhang Y, Proenca R, Maffei M, Barone M, Leopold L, Friedman JM (1994), Positional cloning of the mouse obese gene and its human homologue. Nature 372, 425-432 (erratum in Nature 1995, 374, 479).

144. Edwardson JA, Hough CA (1975), The pituitary-adrenal system of the genetically obese (ob/ob) mouse. J Endocrinol 65, 99-107.

145. Tatemoto K (1982), Neuropeptide Y: complete amino acid sequence of the brain peptide. Proc Natl Acad Sci USA 79, 5485-5489.

146. Allen YS, Adrian TE, Allen JM, Tatemoto K, Crow TJ, Bloom SR, Polak JM (1983), Neuropeptide Y distribution in the rat brain. Science 221, 877-879.

147. Devane WA1, Hanus L, Breuer A, Pertwee RG, Stevenson LA, Griffin G, Gibson D, Mandelbaum A, Etinger A, Mechoulam R (1992), Isolation and structure of a brain constituent that binds to the cannabinoid receptor. Science 258, 1946-1949.

148. Ruegsegger GN, Booth FW (2017), Running from disease: molecular mechanisms associating dopamine and leptin signaling in the brain with physical inactivity, obesity, and type 2 diabetes. Front Endocrinol (Lausanne) 8, 109.

149. Flatow EA, Komegae EN, Fonseca MT, Brito CF, Musteata FM, Antunes-Rodrigues J, Steiner AA (2017), Elucidating the role of leptin in systemic inflammation: a study targeting physiological leptin levels in rats and their macrophages. Am J Physiol Regul Integr Comp Physiol 313, R572-R582.

150. Considine RV, Sinha MK, Heiman ML, Kriauciunas A, Stephens TW, Nyce MR, Ohannesian JP, Marco CC, McKee LJ, Bauer TL, Caro JF (1996), Serum immunoreactive-leptin concentrations in normal-weight and obese humans. N Engl J Med 334, 292-295.

151. Madej T, Boguski MS, Bryant SH (1995), Threading analysis suggests that the obese gene product may be a helical cytokine. FEBS Lett 373, 13-18.

152. Perrier S, Caldefie-Chézet F, Vasson MP (2009), IL-1 family in breast cancer: potential interplay with leptin and other adipocytokines. FEBS Lett 583, 259-265.

153. Cirillo D, Rachiglio AM, la Montagna R, Giordano A, Normanno N (2008), Leptin signaling in breast cancer: an overview. J Cell Biochem 105, 956-964.

154. Jardé T, Perrier S, Vasson MP, Caldefie-Chézet F (2011), Molecular mechanisms of leptin and adiponectin in breast cancer. Eur J Cancer 47, 33-43.
155. Perera CN, Chin HG, Duru N, Camarillo IG (2008), Leptin-regulated gene expression in MCF-7 breast cancer cells: mechanistic insights into leptin-regulated mammary tumor growth and progression. J Endocrinol 199, 221-233.

156. Castellucci M, De Matteis R, Meisser A, Cancello R, Monsurrò V, Islami D, Sarzani R, Marzioni D, Cinti S, Bischof P (2000), Leptin modulates extracellular matrix molecules and metalloproteinases: possible implications for trophoblast invasion. Mol Hum Reprod 6, 951-958.

157. Garofalo C, Surmacz E (2006), Leptin and cancer. J Cell Physiol 207, 12-22.

158. Rouet-Benzineb P, Aparicio Rouet-Benzineb T, Guilmeau S, Pouzet C, Descatoire V, Buyse M, Bado A (2004), Leptin counteracts sodium butyrate-induced apoptosis in human colon cancer HT-29 cells via NF-kappaB signaling. J Biol Chem 279, 16495-16502.

159. Huang ZM, Du SH, Huang LG, Li JH, Xiao L, Tong P (2016), Leptin promotes apoptosis and inhibits autophagy of chondrocytes through upregulating lysyl oxidase-like 3 during osteoarthritis pathogenesis. Osteoarthritis Cartilage 24, 1246-1253.

160. Martínez-Martínez E, Rodríguez C, Galán M, Miana M, Jurado-López R, Bartolomé MV, Luaces M, Islas F, Martínez-González J, López-Andrés N, Cachofeiro V (2016), The lysyl oxidase inhibitor ( $\beta$-aminopropionitrile) reduces leptin profibrotic effects and ameliorates cardiovascular remodeling in diet-induced obesity in rats. J Mol Cell Cardiol 92, 96-104.

161. Ebihara K, Kusakabe T, Hirata M, Masuzaki H, Miyanaga F, Kobayashi N, Tanaka T, Chusho H, Miyazawa T, Hayashi T, Hosoda K, Ogawa Y, DePaoli AM, Fukushima M, Nakao K (2007), Efficacy and safety of leptinreplacement therapy and possible mechanisms of leptin actions in patients with generalized lipodystrophy. J Clin Endocrinol Metab 92, 532-541.

162. Roggenkamp R, Numa S, Schweizer E (1980), Fatty acidrequiring mutant of Saccharomyces cerevisiae defective in acetyl-CoA carboxylase. Proc Natl Acad Sci USA 77, 1814-1817.

163. Hasslacher M, Ivessa AS, Paltauf F, Kohlwein SD (1993), Acetyl-CoA carboxylase from yeast is an essential enzyme and is regulated by factors that control phospholipid metabolism. J Biol Chem 268, 10946-10952.

164. Rios Garcia M, Steinbauer B, Srivastava K, Singhal M, Mattijssen F, Maida A, Christian S, Hess-Stumpp H, Augustin HG, Müller-Decker K, Nawroth PP, Herzig S (2017), Acetyl-CoA carboxylase 1-dependent protein acetylation controls breast cancer metastasis and recurrence. Cell Metabol 26, 842-855.

165. Feng H, Liu Q, Zhang N, Zheng L, Sang M, Feng J, Zhang J, Wu X, Shan B (2013), Leptin promotes metastasis by inducing an epithelial-mesenchymal transition in A549 lung cancer cells. Oncol Res 21, 165-171.

166. Houseknecht KL, Mantzoros CS, Kuliawat R, Hadro E, Flier JS, Kahn BB (1996), Evidence for leptin binding to proteins in serum of rodents and humans: modulation with obesity. Diabetes 45, 1638-1643.

167. van Dielen FM, van't Veer C, Schols AM, Soeters PB, Buurman WA, Greve JW (2001), Increased leptin concentrations correlate with increased concentrations of inflammatory markers in morbidly obese individuals. Int J Obes Relat Metab Disord 25, 1759-1766.

168. Rajala MW, Scherer PE (2003), Minireview: the adipocyte - at the crossroads of energy homeostasis, inflammation, and atherosclerosis. Endocrinology 144, 3765-3773. 
169. Du B, Cawthorn WP, Su A, Doucette CR, Yao Y, Hemati N, Kampert S, McCoin C, Broome DT, Rosen CJ, Yang G, MacDougald OA (2013), The transcription factor paired-related homeobox 1 (Prrx1) inhibits adipogenesis by activating transforming growth factor- $\beta$ (TGF $\beta$ ) signaling. J Biol Chem 288, 3036-3047.

170. Pastel E, Price E, Sjöholm K, McCulloch LJ, Rittig N, Liversedge N, Knight B, Moller N, Svensson PA, Kos K (2017), Lysyl oxidase and adipose tissue dysfunction. Metabolism 78, 118-127.

171. Gottschling-Zeller H, Birgel M, Scriba D, Blum WF, Hauner H (1999), Depot-specific release of leptin from subcutaneous and omental adipocytes in suspension culture: effect of tumor necrosis factor-alpha and transforming growth factor-beta1. Eur J Endocrinol 141, 436-442.

172. Jain M, Budinger GR, Lo A, Urich D, Rivera SE, Ghosh AK, Gonzalez A, Chiarella SE, Marks K, Donnelly HK, Soberanes S, Varga J, Radigan KA, Chandel NS, Mutlu GM (2011), Leptin promotes fibroproliferative acute respiratory distress syndrome by inhibiting peroxisome proliferator-activated receptor- $\gamma$. Am J Respir Crit Care Med 183, 1490-1498.

173. Chen C, Chang YC, Liu CL, Liu TP, Chang KJ, Guo IC (2007), Leptin induces proliferation and anti-apoptosis in human hepatocarcinoma cells by up-regulating cyclin D1 and down-regulating Bax via a Janus kinase 2-linked pathway. Endocr Relat Cancer $14,513-529$

174. Li L, Kubasová T, Rychlik I, Hoerr FJ, Rautenschlein S (2018), Infectious bursal disease virus infection leads to changes in the gut associated-lymphoid tissue and the microbiota composition. PLoS One 13, e0192066.

175. Sobhani I, Tap J, Roudot-Thoraval F, Roperch JP, Letulle S, Langella P, Corthier G, Tran Van Nhieu J, Furet JP (2011), Microbial dysbiosis in colorectal cancer (CRC) patients. PloS One 6, e16393.

176. Manichanh C, Rigottier-Gois L, Bonnaud E, Gloux K, Pelletier E, Frangeul L, Nalin R, Jarrin C, Chardon P, Marteau P, Roca J, Dore J (2006), Reduced diversity of faecal microbiota in Crohn's disease revealed by a metagenomic approach. Gut 55, 205-211.

177. Brücher BLDM, Jamall IS (2019), Undervalued ubiquitous proteins. 4open 2, 7, 1-13. https://doi.org/10.1051/ fopen $/ 2019002$

178. Brücher BLDM, Jamall IS (2019), Precancerous niche (PCN), a product of fibrosis with remodeling by incessant chronic inflammation. 4open 2, 11, 1-21. https://doi.org/ $10.1051 /$ fopen/2018009

Cite this article as: Brücher BLDM, Jamall IS. (2019), Microbiome and morbid obesity increase pathogenic stimulus diversity. 4open, 2, 10 . 